\title{
Fatty acid profile of zebu beef cattle from the Central African sub-region
}

\author{
B.M. Nfor ${ }^{1,2,3}$, M. Corazzin², F.A. Fonteh ${ }^{3}$, A. Sepulcri' ${ }^{2}$, N.T. Aziwo ${ }^{3}$ \& E. Piasentier ${ }^{2 \#}$ \\ ${ }^{1}$ Livestock Development Corporation “SODEPA", P.O. 1410, Yaoundé, Cameroon \\ ${ }^{2}$ Department of Agriculture and Environmental Science, University of Udine, via Sondrio 2, 33100, Udine, Italy \\ ${ }^{3}$ Department of Animal Production, University of Dschang, P.O. 222, Dschang, Cameroon
}

(Received 4 December 2013; Accepted 5 May 2014; First published online 7 June 2014)

Copyright resides with the authors in terms of the Creative Commons Attribution 2.5 South African Licence.
See: http://creativecommons.org/licenses/by/2.5/za
Condition of use: The user may copy, distribute, transmit and adapt the work, but must recognise the authors and the South African
Journal of Animal Science

\begin{abstract}
This study analysed the meat fatty acid (FA) composition of three zebu breeds, Gudali (GU), White Fulani (WF) and Red Mbororo (RM), raised on savannah pasture and monitored in the commercial context of the Yaoundé abattoir. Samples of $m$. longissimus thoracis from 60 bulls belonging to the GU, WF and RM breeds were collected and analysed for fat and FA composition. The fat content of the meat was low, but similar across breeds $(1.34 \pm 0.912 \mathrm{~g} / 100 \mathrm{~g}$ muscle, mean $\pm \mathrm{SD})$. Meat from the GU breed had higher C18:3n-3 and C22:5n-3 proportions and lower C18:0 and total saturated FA proportions than WF meat. Red Mbororo meat had an intermediate FA composition compared with the other breeds. The elongase and $\Delta 9$ desaturase indices were comparable among breeds. In summary, the results indicate that there are minimal differences in beef FA composition of the three breeds from the Central African sub-region. Additionally, based on the polyunsaturated FA (PUFA) proportion, $13.9 \%$ of the total lipids and $n-6 / n-3$ PUFA ratio, 1.95, consumption of beef from these breeds could be beneficial to human health. This is possibly owing to the pasture feeding and low fat content of the beef.
\end{abstract}

Keywords: Intramuscular fat, fatty acid composition, natural pasture

\#Corresponding author: edi.piasentier@uniud.it

\section{Introduction}

The Central African sub-region is the smallest beef market in Africa. In the near future, this region, together with the Western African region, will have the largest increase in beef consumption in Africa (Livestock Data Innovation in Africa Project, 2013). The importance of meat as a source of high biological value proteins and micronutrients (vitamins $A, B_{6}, B_{12}, D$ and $E$, and iron, zinc and selenium) is well recognized (Biesalski, 2005; Muchenje et al., 2009a). However, beef fat has a relatively high ratio of saturated to unsaturated fatty acids (SFA/UFA) in comparison with the meat from monogastric species. This is a risk factor in the development of vascular and coronary diseases (Calder, 2004).

Breed, together with age and nutrition of animals, is the most important factor influencing the content and composition of meat fat (Smith et al., 2009; Mapiye et al., 2012). In the Central African sub-region, beef is produced from zebu cattle, the main breeds being Red Mbororo and White Fulani. Both breeds belong to the Fulani group, but present distinct characteristics that justify their separate breed status (Ibeagha-Awemu \& Erhardt, 2006). However, in Cameroon, which is the main producer of zebu cattle in the Central African sub-region, the Gudali is the predominant beef cattle breed (Pamo, 2008). To the knowledge of the researchers, there is limited information on the fatty acid (FA) composition of African zebu breeds (Muchenje et al., 2009b). Therefore, the aim of this study was to compare the FA composition of Gudali (GU), White Fulani (WF) and Red Mbororo (RM) bulls raised on savannah pasture.

\section{Materials and Methods}

The study complies with the current laws of Cameroon (Decree No. 76/420, and No. 86/755). Approximately 2000 cattle were processed individually at the Livestock Development Corporation (SODEPA) 
Yaoundé abattoir between January 2009 and March 2012. The animals were then slaughtered, and the carcass weight recorded. As reported by Nfor et al. (2014), 99.2\% of the slaughtered cattle were zebu belonging to the GU, WF and RM breeds, and $60 \%$ were bulls. The majority $(75 \%)$ of cattle processed at the facility was raised under the transhumant pastoral system, characterized by the organized displacement of cattle herds during the dry season. To represent the animals slaughtered in terms of cattle category, breed, age and carcass weight within breed, 60 zebu bulls belonging to the $G U(n=19)$, WF $(n=20)$ and RM $(n=$ 21 ) breeds were selected. The age at slaughter was similar for the breeds (median $=4 ; \min .=3 ; \max .=5$ years). The GU breed $(174.6 \mathrm{~kg})$ had a higher average carcass weight than the WF $(153.7 \mathrm{~kg})$ and RM $(153.2 \mathrm{~kg})$ breeds. The experimental bulls were previously raised on Guinea savannah pasture, which is a mixture of trees and grass species such as Hyparrhenia, Panicum and Setaria spp. (Deffo et al., 2011; Pamo, 2008). The diet consisted mostly of herbage, grazed in the dry and rainy seasons.

After chilling at $4{ }^{\circ} \mathrm{C}$ for 24 hours, a sample of approximately $400 \mathrm{~g}$ of $\mathrm{m}$. longissimus thoracis was taken from the left side of the carcass by cutting a three-centimetre thick steak from the section dividing the thoracic and lumbar parts of the muscle (i.e. between the 12th and 13th ribs). The sample was then vacuumpacked, frozen rapidly and stored at $-20^{\circ} \mathrm{C}$ until FA analysis.

Extraction of total lipids was performed according to the procedure of Folch et al. (1957). A total of 15 $\mathrm{mg}$ of nonadecanoic acid (C19:0) was added to a $1.5 \mathrm{~g}$ sample of minced meat and homogenised in $30 \mathrm{~mL}$ of a chloroform-methanol mixture $(2: 1 \mathrm{v} / \mathrm{v})$ using an Ultra-Turrax homogeniser ( $T 25$ basic; Ika-Werke, Staufen, Germany). The sample was subsequently filtered under vacuum through a Whatman No. 1820-047 filter paper. The extract was washed with $8.5 \mathrm{~mL}$ of $0.88 \%(\mathrm{w} / \mathrm{v}) \mathrm{KCl}$, mixed vigorously for $60 \mathrm{~s}$, and then left overnight at room temperature. The organic phase was separated, and the solvents were evaporated under vacuum at $40{ }^{\circ} \mathrm{C}$. Fatty acid methyl esters (FAME) were prepared using methanolic $\mathrm{HCl}$ (Sukhija \& Palmquist, 1988). Lipid samples were mixed with $2 \mathrm{~mL}$ of hexane and $3 \mathrm{~mL}$ of methanolic $\mathrm{HCl}$ in $20 \mathrm{~mL}$ glass tubes with Teflon-lined caps. The mixture was heated at $70{ }^{\circ} \mathrm{C}$ for 2 hours, and then cooled to room temperature. The FAME was extracted in $2 \mathrm{~mL}$ of hexane after the addition of $5 \mathrm{~mL}$ of $6 \%(\mathrm{w} / \mathrm{v}) \mathrm{K}_{2} \mathrm{CO}_{3}$ and $\mathrm{Na}_{2} \mathrm{SO}_{4}$ anhydrous. Samples stayed for $30 \mathrm{~min}$ prior to centrifugation at $1006 \times \mathrm{g}$ for $10 \mathrm{~min}$ at $20{ }^{\circ} \mathrm{C}$. The upper hexane layer was removed, concentrated under $\mathrm{N}_{2}$ and diluted in hexane. The FAME was separated with a Carlo Erba gas chromatograph (GC) (HRGC 5300 mega-series; Rodano, Milan, Italy) fitted with an automatic sampler (model A200S; Rodano, Milan, Italy) and a flame ionisation detector (FID). A $1 \mu \mathrm{L}$ sample was injected in $1: 30$ split mode. The GC was equipped with a $60 \mathrm{~m} \mathrm{SP-2380} \mathrm{fused} \mathrm{silica} \mathrm{capillary} \mathrm{column}$ ( $0.25 \mathrm{~mm}$ i.d., film thickness $0.25 \mu \mathrm{m}$; Supelco Inc., Bellafonte, PA), and the oven temperature was increased from 160 to $180^{\circ} \mathrm{C}$ at $1{ }^{\circ} \mathrm{C} / \mathrm{min}$, from 180 to $260^{\circ} \mathrm{C}$ at $5^{\circ} \mathrm{C} / \mathrm{min}$ and then held at $260^{\circ} \mathrm{C}$ for $5 \mathrm{~min}$. Helium was used as the carrier gas at the rate of $1.2 \mathrm{~mL} / \mathrm{min}$, and FAME were identified using external standards (Supelco 37-component FAME mix, including conjugated linoleic acids; Sigma-Aldrich, Milan, Italy). The FAME were quantified using C19:0 as the internal standard and were expressed as the percentage of the total lipids that were identified. The $\Delta 9$ desaturase, elongase and atherogenic indices were calculated according to Bartoň et al. (2010), Pitchford et al. (2002) and Ulbricht \& Southgate (1991), respectively, as follows:

$\Delta 9$ desaturase index $=100 \times(\mathrm{C} 14: 1 n-9 \mathrm{c}+\mathrm{C} 16: 1 n-9 \mathrm{c}+\mathrm{C} 18: 1 n-9 \mathrm{c}+\mathrm{CLA}) /(\mathrm{C} 14: 1 n-9 \mathrm{c}+\mathrm{C} 16: 1 n-9 \mathrm{c}+$ $\mathrm{C} 18: 1 n-9 \mathrm{c}+\mathrm{CLA}+\mathrm{C} 14: 0+\mathrm{C} 16: 0+\mathrm{C} 18: 0+\mathrm{C} 18: 1 \mathrm{t})$

elongase index $=100 \times[(\mathrm{C} 18: 0+\mathrm{C} 18: 1 n-9 \mathrm{c}) /(\mathrm{C} 16: 0+\mathrm{C} 16: 1 n-9 \mathrm{c}+\mathrm{C} 18: 0+\mathrm{C} 18: 1 n-9 \mathrm{c})]$

atherogenic index $=[\mathrm{C} 12: 0+4(\mathrm{C} 14: 0)+\mathrm{C} 16: 0] /(\mathrm{SFA}+\mathrm{PUFA})$

where C14:1n-9c, C16:1n-9c, C18:1n-9c, CLA, C14:0, C16:0, C18:0, C18:1t, C12:0, SFA and PUFA are myristoleic acid, palmitoleic acid, oleic acid, sum of CLA isomers, myristic acid, palmitic acid, stearic acid, trans-C18:1 acids, lauric acid, saturated fatty acids and polyunsaturated fatty acids, respectively.

The statistical analyses were performed with the free software $R$ version 2.15.2. The normality of the data distribution and homogeneity of variance were tested with the Shapiro-Wilk and Levene tests, respectively. Data were subjected to one-way analysis of variance (ANOVA) with breed as the fixed effect. The Tukey-Kramer test for unequal sample size was used as a post-hoc test. If the ANOVA assumptions were not verified, multiple comparisons were performed according to the Herberich et al. (2010) procedure. Pearson coefficients were used to determine associations between FAs and intramuscular fat content (chloroform-methanol extractable fat) of $\mathrm{m}$. longissimus thoracis. A probability level of $P \leq 0.05$ was established for statistical significance. 


\section{Results and Discussion}

The total lipid weight and relative proportion of FA in $m$. longissimus thoracis according to breed are shown in Table 1. The intramuscular fat content of meat was low (mean \pm SD, $1.34 \pm 0.912 \mathrm{~g} / 100 \mathrm{~g}$ muscle) and did not differ across breeds. This was possibly because of the lack of genetic selection of the animals (Deffo et al., 2011). Intramuscular fat content in the current study is comparable with that reported by Salifu et al. (2013) in Fulani bulls. However, the IMF content of beef from Nguni and Bonsmara steers raised on natural pasture was lower in the study by Muchenje et al. (2009b). Savell \& Cross (1988) suggested a minimum of $3 \%$ fat to ensure acceptable palatability of beef. Given that fat content from the present study was below this threshold, meat from the three breeds could be poorly palatable.

Overall, breed had a limited effect on the FA profile of meat in the current study. This is in agreement with the general conclusion of De Smet et al. (2004). In studies with Canchim and Canchim $\times$ Charolais (Do Prado et al., 2009) and Nguni and Bonsmara cattle (Muchenje et al., 2009b), breed was also reported to have a small effect on FA composition of meat. However, in the current study, the FA profile of beef of the GU tended to be similar to that of the RM breed, with the only exception being that C18:0 was lower in GU than in RM beef. Considering the linear odd-chain FAs, GU had higher tridecanoic acid (C13:0), lower pentadecanoic acid (C15:0), and tended to have lower margaric acid (C17:0) proportions $(P=0.08)$ relative to WF beef. These results could be explained by genetic differences between the breeds related to de novo C15:0 and C17:0 syntheses from propionate in adipose tissue (Vlaeminck et al., 2006). Bressan et al. (2011) have suggested that differences in gastrointestinal tract and rumen volume between breeds can influence the ruminal microbial ecosystem, which could also explain observations made in the current study. This appears to be confirmed by the different $\alpha$-linolenic acid (C18:3n-3) and C18:0 proportions of GU compared with WF beef. Indeed, beef from GU had a higher C18:3n-3 proportion, and tended to have higher linoleic acid $(\mathrm{C} 18: 2 n-6)(P=0.10)$ and lower C18:0 proportions than WF beef. Considering that C18:3n-3 and C18:2n-6 FAs are exclusively of dietary origin, and C18:0 is an end-product of the bio-hydrogenation of dietary UFA, it could be speculated that ruminal bio-hydrogenation of dietary fat occurred to a lower extent in GU than in WF cattle. Meat docosapentaenoic acid (C22:5n-3), which is derived from C18:3n-3 FA, was higher in GU and RM than in WF beef. The proportions of total monounsaturated FA (MUFA) and $n-6$ PUFA were not affected by breed, whereas the SFA was lower in GU than in WF, and PUFA and $n-3$ PUFA were higher in GU and RM than in WF beef.

On average, total PUFA and $n-3$ PUFA were $13.9 \%$ and $4.6 \%$ of total lipids, respectively, which is consistent with the values reported by Salifou et al. (2013) for Fulani zebu (mixed breeds) from Benin. However, total PUFA and n-3 PUFA were higher in Nguni and Bonsmara steers from South Africa (Muchenje et al., 2009b), whereas they were lower in Nellore cattle and in Nellore crossings with Simmental and Santa Gertrudes from South America (Ruiz et al., 2005; Padre et al., 2006). Since cattle in all these studies were raised on natural pasture, the differences in total PUFA and n-3 PUFA could possibly be explained by differences in age of slaughter and levels of marbling (Mapiye et al., 2012). In the current study, $n-6 / n-3$ PUFA and PUFA/SFA ratios were similar across breeds and the mean $n-6 / n-3$ PUFA ratio was 1.95 . From a human health perspective, the maximum recommended $n-6 / n-3$ PUFA ratio to reduce the risk of coronary heart disease is 4.0 (English Department of Health, 1994). The natural pasture-based diet, characterized by a high proportion of linolenic acid (Webb \& Erasmus, 2013), may explain the lack of differences between breeds and the low $n-6 / n-3$ ratio of beef. The minimum PUFAISFA ratio recommended for human health is 0.45 (Simopoulos, 2004), a value much higher than the mean value of 0.29 reported in this study. This inability to achieve the optimum PUFA/SFA ratio is well documented in both Bos taurus (Piasentier et al., 2009; Corazzin et al., 2012; Ripoll et al., 2014) and Bos indicus (Ruiz et al., 2005; Bressan et al., 2011) cattle owing to the extensive bio-hydrogenation of the dietary UFA by the rumen microorganisms. The atherogenic index, which is an indicator for the risk of cardiovascular disease, should be as low as possible. This index did not vary among the tested breeds. The CLA content of beef from the three breeds was similar, and the average value $(0.28 \%$ of total lipids) falls within the range reported in literature for zebu and zebuderived cattle $(0.15 \%$ to $0.43 \%$ of total lipids) raised on natural pastures around the world (De Mendoza et al., 2005; Muchenje et al., 2009b; Salifu et al., 2013). Based on FA composition in the current study, consumption of beef from the GU, WF and RM breeds could be beneficial to human health.

The major FAs in the current study were C16:0, C18:0, C18:1n-9c and C18:2n-6c. As reported in Table 2, C16:0 and C18:1n-9c were positively correlated, whereas C18:2n-6c was negatively correlated with the intramuscular fat content of the $m$. longissimus thoracis. No statistically significant correlation was found between C18:0 and the total fat content. Moreover, SFA and MUFA were positively correlated, whereas PUFA was negatively correlated with the intramuscular fat content. These results are in close agreement with the findings of Brugiapaglia et al. (2014) in Bos taurus breeds, and are caused by the decrease in the phospholipids/neutral lipids ratio that arises from the increase in the intramuscular fat, as shown by Itoh et al. (1999) in steers of Bos taurus breeds. 
Table 1 Estimated marginal means of fatty acid total weight ( $\mathrm{g} / 100 \mathrm{~g}$ muscle) and proportion (percentage of total fatty acids) of $m$. longissimus thoracis depending on bull breed ${ }^{1}$

\begin{tabular}{|c|c|c|c|c|}
\hline Fatty acids & $\begin{array}{c}\text { Gudali } \\
(n=19)\end{array}$ & $\begin{array}{l}\text { White Fulani } \\
\quad(n=20)\end{array}$ & $\begin{array}{l}\text { Red Mbororo } \\
(n=21)\end{array}$ & SEM \\
\hline Total weight & 1.38 & 1.58 & 1.09 & 0.118 \\
\hline C10:0 & 0.08 & 0.07 & 0.11 & 0.071 \\
\hline C12:0 & 0.12 & 0.10 & 0.13 & 0.005 \\
\hline C13:0 & $0.25^{\mathrm{a}}$ & $0.11^{\mathrm{b}}$ & $0.21^{a}$ & 0.018 \\
\hline C14:0 & 2.31 & 2.53 & 2.40 & 0.100 \\
\hline $\mathrm{C} 14: 1 n-9 \mathrm{c}$ & 0.27 & 0.30 & 0.28 & 0.017 \\
\hline C15:0 & $0.29^{b}$ & $0.37^{a}$ & $0.35^{\mathrm{ab}}$ & 0.012 \\
\hline C15:1 & 0.17 & 0.18 & 0.18 & 0.013 \\
\hline C16:0 & 24.7 & 25.5 & 24.5 & 0.438 \\
\hline C16:1n-9t & 0.57 & 0.45 & 0.48 & 0.051 \\
\hline $\mathrm{C} 16: 1 n-9 \mathrm{c}$ & 2.21 & 2.09 & 2.18 & 0.084 \\
\hline C17:0 & 1.03 & 1.15 & 1.13 & 0.022 \\
\hline C17:1 & 0.51 & 0.61 & 0.55 & 0.025 \\
\hline C18:0 & $18.0^{\mathrm{b}}$ & $20.7^{\mathrm{a}}$ & $19.8^{\mathrm{a}}$ & 0.279 \\
\hline${ }^{2}$ trans-C18:1 & 1.98 & 2.09 & 1.85 & 0.083 \\
\hline $\mathrm{C} 18: 1 n-9 \mathrm{c}$ & 29.2 & 29.0 & 27.5 & 0.500 \\
\hline C18:1n-7 & 2.62 & 2.60 & 2.58 & 0.067 \\
\hline C18:2n-6t & 0.16 & 0.15 & 0.17 & 0.017 \\
\hline C18:2n-6c & 6.34 & 4.61 & 5.92 & 0.349 \\
\hline C18:3n-6 & $0.18^{\mathrm{b}}$ & $0.36^{a}$ & $0.13^{\mathrm{b}}$ & 0.046 \\
\hline C18:3n-3 & $2.34^{\mathrm{a}}$ & $1.61^{\mathrm{b}}$ & $2.16^{\mathrm{ab}}$ & 0.124 \\
\hline CLAt7,c9/t8,c10/c9,t11 & 0.29 & 0.30 & 0.26 & 0.015 \\
\hline $\mathrm{C} 20: 3 n-6$ & 0.39 & 0.34 & 0.48 & 0.027 \\
\hline$C 20: 3 n-3$ & 0.01 & 0.03 & 0.11 & 0.035 \\
\hline$C 20: 4 n-6$ & 2.65 & 1.94 & 2.94 & 0.162 \\
\hline$C 20: 5 n-3$ & $0.96^{\mathrm{ab}}$ & $0.73^{b}$ & $1.18^{\mathrm{a}}$ & 0.070 \\
\hline $\mathrm{C} 22: 5 n-3$ & $1.62^{\mathrm{a}}$ & $1.17^{\mathrm{b}}$ & $1.60^{\mathrm{a}}$ & 0.077 \\
\hline$C 22: 6 n-3$ & 0.12 & 0.15 & 0.13 & 0.011 \\
\hline C23:0 & 0.13 & 0.14 & 0.13 & 0.011 \\
\hline $\mathrm{C} 24: 0$ & 0.13 & 0.16 & 0.15 & 0.011 \\
\hline$C 24: 1 n-9$ & 0.11 & 0.20 & 0.19 & 0.019 \\
\hline SFA & $47.2^{\mathrm{b}}$ & $51.0^{\mathrm{a}}$ & $49.1^{\mathrm{ab}}$ & 0.546 \\
\hline MUFA & 37.7 & 37.6 & 35.8 & 0.538 \\
\hline PUFA & $15.2^{\mathrm{a}}$ & $11.4^{\mathrm{b}}$ & $15.2^{\mathrm{a}}$ & 0.750 \\
\hline Total $n-6$ PUFA & 9.83 & 7.45 & 9.73 & 0.538 \\
\hline Total $n-3$ PUFA & $5.05^{\mathrm{a}}$ & $3.69^{b}$ & $5.18^{\mathrm{a}}$ & 0.240 \\
\hline MUFA/SFA & 0.803 & 0.743 & 0.733 & 0.014 \\
\hline PUFA/SFA & 0.331 & 0.230 & 0.322 & 0.019 \\
\hline$n-6 / n-3$ & 1.93 & 2.04 & 1.88 & 0.049 \\
\hline Atherogenic index & 0.549 & 0.574 & 0.537 & 0.013 \\
\hline Elongase index & 63.8 & 64.4 & 64.0 & 0.397 \\
\hline$\Delta 9$ Desaturase Index & 40.6 & 38.5 & 38.4 & 0.482 \\
\hline
\end{tabular}

\footnotetext{
${ }^{1}$ Fatty acids detected at $<0.1 \%$ of total lipids are not reported.

SEM: standard error of the mean.

CLA: conjugated linoleic acid; SFA: saturated fatty acids; MUFA: monounsaturated fatty acids; PUFA: polyunsaturated fatty acids.

${ }^{a, b}$ Row means with different superscripts differ significantly at $P<0.05$.

${ }^{2}$ trans-C18:1 corresponds to the sum of t6-8-, t9-, t10-, t11-, t12- and t13/14-18:1.
}

Indeed, C16:0, C18:1n-9c and total SFA are present mainly in the neutral fraction, whereas C18:2n-6c and total PUFA are present mainly in the phospholipids fraction. The elongase index was not correlated with 
the total fat content $(P=0.12)$. Kazala et al. (1999) reported only a moderate negative correlation between the elongase index and the total lipid content $(r=-0.31 ; P<0.10)$ of the longissimus muscle of crossbreed Wagyu cattle. No statistically significant correlation was found between the $\Delta 9$ desaturase index and total lipid content. These results are in agreement with the findings of Corazzin et al. (2013), which showed no differences in the $\Delta 9$ desaturase index when comparing animals with different subcutaneous fat deposits, but in contrast with the findings of Jiang et al. (2008), who reported a positive correlation between $\Delta 9$ desaturase activity and the marbling of beef.

Table 2 Correlation between fatty acid composition and intramuscular fat content of $m$. longissimus thoracis ${ }^{1}$

\begin{tabular}{|c|c|c|}
\hline Fatty acids & $\mathbf{r}$ & Significance level \\
\hline C10:0 & -0.092 & ns \\
\hline C12:0 & -0.233 & * \\
\hline C13:0 & -0.450 & 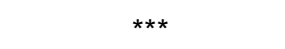 \\
\hline C14:0 & 0.359 & $\star \star$ \\
\hline $\mathrm{C} 14: 1 n-9 \mathrm{c}$ & 0.261 & * \\
\hline $\mathrm{C} 15: 0$ & -0.004 & ns \\
\hline C15:1 & -0.436 & $\star \star$ \\
\hline C16:0 & 0.497 & $\star \star \star$ \\
\hline $\mathrm{C} 16: 1 n-9 \mathrm{t}$ & -0.142 & ns \\
\hline $\mathrm{C} 16: 1 n-9 \mathrm{c}$ & 0.285 & * \\
\hline $\mathrm{C} 17: 0$ & -0.144 & ns \\
\hline C17:1 & -0.246 & ns \\
\hline C18:0 & 0.136 & ns \\
\hline${ }^{2}$ trans-C18:1 & 0.229 & ns \\
\hline $\mathrm{C} 18: 1 n-9 \mathrm{c}$ & 0.416 & ** \\
\hline $\mathrm{C} 18: 1 n-7$ & 0.009 & ns \\
\hline C18:2n-6t & -0.293 & * \\
\hline C18:2n-6c & -0.608 & $\star \star \star ~$ \\
\hline $\mathrm{C} 18: 3 n-6$ & -0.074 & ns \\
\hline C18:3n-3 & -0.567 & $\star \star \star$ \\
\hline CLAt7,c9/t8,c10/c9,t11 & 0.396 & $\star *$ \\
\hline$C 20: 3 n-6$ & -0.497 & $\star \star \star$ \\
\hline$C 20: 3 n-3$ & -0.046 & ns \\
\hline C20:4n-6 & -0.551 & $* * *$ \\
\hline$C 20: 5 n-3$ & -0.490 & 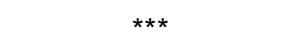 \\
\hline$C 22: 5 n-3$ & -0.647 & $\star * *$ \\
\hline$C 22: 6 n-3$ & -0.203 & ns \\
\hline C23:0 & -0.348 & $\star \star$ \\
\hline C24:0 & -0.367 & $\star \star$ \\
\hline C24:1n-9 & -0.249 & ns \\
\hline SFA & 0.471 & $\star * *$ \\
\hline MUFA & 0.428 & $\star \star$ \\
\hline PUFA & -0.650 & $\star \star \star *$ \\
\hline Total $n-6$ PUFA & -0.627 & $\star \star \star ~$ \\
\hline Total $n-3$ PUFA & -0.654 & $\star \star \star$ \\
\hline Atherogenic index & 0.591 & $\star \star \star$ \\
\hline Elongase index & -0.198 & ns \\
\hline$\Delta 9$ Desaturase index & 0.062 & ns \\
\hline
\end{tabular}

${ }^{1}$ Fatty acids detected at $<0.1 \%$ of total lipids are not reported.

CLA: conjugated linoleic acid; SFA: saturated fatty acids; MUFA: monounsaturated fatty acids;

PUFA: polyunsaturated fatty acids.

Level of significance:* $P<0.05$; ${ }^{\star *} P<0.01 ;{ }^{* \star \star} P<0.001$; ns: not significant.

${ }^{2}$ trans-C18:1 corresponds to the sum of t6-8-, t9-, t10-, t11-, t12- and t13/14-18:1. 


\section{Conclusions}

Results from this study indicate that there are marginal differences in FA composition of beef from Gudali, White Fulani and Red Mbororo breeds reared in the transhumance system of the Central African sub-region. This could be attributed to the lack of genetic selection and the similar herbage foraged by cattle. Additionally, based on the polyunsaturated FA (PUFA) proportion and $n-6 / n-3$ PUFA ratio, consumption of beef from these breeds could be beneficial to human health.

\section{Acknowledgements}

This study was conducted through international collaboration between the University of Udine, Italy, and the University of Dschang, Cameroon, and was supported by the Regional Decentralised Cooperation programmes of Friuli Venezia Giulia Region (LR 19/2000), Italy, Ministry of Livestock, Fisheries and Animal Industries (MINEPIA) and Livestock Development Corporation (SODEPA), Cameroon.

\section{References}

Bartoň, L., Bureš, D. \& Kudrna, V., 2010. Meat quality and fatty acid profile of the muscle longissimus lomborum in Czech Fleckvieh, Charolais, Charolais $\times$ Czech Fleckvieh bulls fed different types of silage. Czech J. Anim. Sci. 55, 479-487.

Biesalski, H.K., 2005. Meat component of a healthy diet. Are there any risks or benefits if meat is avoided in the diet? Meat Sci. 70, 509-524.

Bressan, M.C., Rossato, L.V., Rodrigues, E.C., Alves, S.P., Bessa, R.J.B., Ramos, E.M. \& Gama, L.T., 2011. Genotype $\times$ environment interactions for fatty acid profiles in Bos indicus and Bos taurus finished on pasture or grain. J. Anim. Sci. 89, 221-232.

Brugiapaglia, A., Lussiana, C. \& Destefanis, G., 2014. Fatty acid profile and cholesterol content of beef at retail of Piemontese, Limousin and Frisian breeds. Meat Sci. 96, 568-573.

Calder, P.C., 2004. N-3 fatty acids and cardiovascular disease evidence explained and mechanisms explored. Clin. Sci. 107, 1-11.

Corazzin, M., Bovolenta, S., Sepulcri, A. \& Piasentier, E., 2012. Effect of whole linseed addition on meat production and quality of Italian Simmental and Holstein young bulls. Meat Sci. 90, 99-105.

Corazzin, M., Bovolenta, S., Saccà, E., Bianchi, G. \& Piasentier, E., 2013. Effect of linseed addition on the expression of same metabolism genes in the adipose tissue of young Italian Simmental and Holstein bulls. J. Anim. Sci. 91, 405-421.

Deffo, V., Pamo, E.T., Tchotsoua, M., Lieugomg, M., Arene, C.J. \& Nwagbo, E.C., 2011. Determination of the critical period for cattle farming in Cameroon. Int. J. Livest. Prod. 2, 59-68.

De Mendoza, G.M., de Moreno, L.A., Huerta-Leidenz, N., Uzćategui-Bracho, B., Beriain, M.J. \& Smith, G.C., 2005. Occurrence of conjugated linoleic acid in longissimus dorsi muscle of water buffalo (Bubalus bubalis) and zebu-type cattle raised under savannah conditions. Meat Sci. 69, 93-100.

De Smet, S., Raes, K. \& Demeyer, D., 2004. Meat fatty acid composition as affected by fatness and genetic factors: a review. Anim. Res. 53, 81-98.

Do Prado, I.N., De Oliveira, A.N., Rotta, P.R., Perotto, D., Do Prado, R.M., Silva, R.R., De Souza, N.E. \& Moletta, J.L., 2009. Chemical and fatty acid composition of longissimus muscle of crossbred bulls finished in feedlot. Asian-Austral. J. Anim. Sci. 22, 1054-1059.

English Department of Health, 1994. Nutritional aspects of cardiovascular disease. Report of the Panel on Dietary Reference Values of the Committee on Medical Aspects of Food Policy. Report on Health and Social Subjects, vol. 46. Her Majesty's Stationery Office, London.

Folch, J., Lees, M. \& Sloane Stanley, G.H., 1957. A simple method for isolation and purification of total lipids from animal tissues. J. Biol. Chem. 226, 497-509.

Herberich, E., Sikorski, J. \& Horthorn, T., 2010. A robust procedure for comparing multiple means under heteroscedasticity in unbalanced designs. PLoS. ONE 5, e9788.

Ibeagha-Awemu, M.E. \& Erhardt, G., 2006. An evaluation of genetic diversity indices of the Red Bororo and White Fulani cattle breeds with different molecular markers and their implications for current and future options. Trop. Anim. Health Pro. 38, 431-441.

Itoh, M., Johnson, C.B., Cosgrove, G.P., Muir, P.D. \& Purchas, R.W., 1999. Intramuscular fatty acid composition of neutral and polar lipids for heavy-weight Angus and Simmental steers finished on pasture or grain. J. Sci. Food Agric. 79, 821-827.

Jiang, Z., Michal, J.J., Tobey, D.J., Daniels, T.F., Rule, D.C. \& MacNeil, M.D., 2008. Significant associations of stearoyl-CoA desaturase (SCD1) gene with fat deposition and composition in skeletal muscle. Int. J. Biol. Sci. 4, 345-351. 
Kazala, E.C., Lozeman, F.J., Mir, P.S., Laroche, A., Bailey, D.R. \& Weselake, R.J., 1999. Relationship of fatty acid composition to intramuscular fat content in beef from crossbred Wagyu cattle. J. Anim. Sci. 77, 1717-1725.

Livestock Data Innovation in Africa Project, 2013. Investing in African livestock: business opportunities in 2030-2050. http://www.fao.org/docrep/018/al757e/al757e.pdf (accessed November 2013).

Mapiye, C., Aldai, N., Turner, T.D., Aalhus, J.L., Rolland, D.C., Kramer, J.K.G. \& Dugan, M.E.R., 2012. The labile lipid fraction of meat: From perceived disease and waste to health and opportunity. Meat Sci. 92, 210-220.

Muchenje, V., Dzama, K., Chimonyo, M., Strydom, P.E., Hugo, A. \& Raats, J.G., 2009a. Some biochemical aspects pertaining to beef eating quality and consumer health: A review. Food Chem. 112, 279-289.

Muchenje, V., Hugo, A., Dzama, K., Chimonyo, M., Strydom, P.E. \& Raats, J.G., 2009b. Cholesterol levels and fatty acid profiles of beef from three cattle breeds raised on natural pasture. J. Food Comp. Anal. 22, 354-358.

Nfor, B.M., Corazzin, M., Fonteh, F.A., Aziwo, N.T., Galeotti, M. \& Piasentier, E., 2014. Quality and safety of beef produced in Central African Sub-region. Ital. J. Anim. Sci. 13, 392-397.

Padre, R.G., Aricetti, J.A., Moreira, F.B., Mizubuti, I.Y., Prado, I.N., Visentainer, J.W., Souza, N.E. \& Matsushita, M., 2006. Fatty acids profile, and chemical composition of longissimus muscle of bovine steers and bulls finished in pasture system. Meat Sci. 74, 242-248.

Pamo, E.T., 2008. Country Pasture/Forage Resource Profile: Cameroon. Eds: Suttle, J.M. \& Reynolds, S.G., FAO, Rome, Italy.

Piasentier, E., Bovolenta, S., Moioli, B., Orrù, L., Valusso, R. \& Corazzin, M., 2009. Fatty acid composition and sensory properties of Italian Simmental beef as affected by genes frequency of Montbéliarde origin. Meat Sci. 83, 543-550.

Pitchford, W.S., Deland, M.P.B., Siebert, B.D., Malau-Aduli, A.E.O. \& Bottema, C.D.K., 2002. Genetic variation in fatness and fatty acid composition of crossbred cattle. J. Anim. Sci. 80, 2825-2832.

Ripoll, G., Blanco, M., Alberti, P., Panea, B., Joy, M. \& Casasús, I., 2014. Effect of two Spanish breeds and diet on beef quality including consumer preferences. J. Sci. Food. Agric. 94, 983-992.

Ruiz, M.R., Matsushita, M., Visentainer, J.V., Hernandez, J.A., De Ribeiro, E.L., Shimokomaki, M., Reeves, J.J. \& De Souza, N.E., 2005. Proximate chemical composition and fatty acid profile of longissimus thoracis from pasture fed LHRH immunocastrated, castrated and intact Bos indicus bulls. S. Afr. J. Anim. Sci. 35, 13-18.

Salifou, C.F.A., Dahouda, M., Houaga, I., Picard, B., Hornick, J.L., Micol, D., Kassa, S.K., Farougou, F., Mensah, G.A., Clinquart, A. \& Youssao, A.K.I., 2013. Muscle characteristics, meat tenderness and nutritional qualities traits of Borgou, Lagunaire and zebu Fulani bulls raised on natural pasture in Benin. Int. J. Anim. Vet. Adv. 5, 143-155.

Savell, J.W. \& Cross, H.R., 1988. The role of fat in the palatability of beef, pork, and lamb. In: Designing foods: animal product options in the marketplace. Ed. National Academy Press, Washington, D.C., USA.

Simopoulos, A.P., 2004. Omega-6 / omega-3 essential fatty acid ratio and chronic diseases. Food Rev. Int. 20, 77-90.

Smith, S.B., Gill, C.A., Lunt, D.K. \& Brooks, M.A., 2009. Regulation of fat and fatty acid composition in beef cattle. Asian-Austral. J. Anim. Sci. 22, 1225-1233.

Sukhija, P.S. \& Palmquist, D.L., 1988. Rapid method for determination of fatty acid content and composition of feedstuffs and feces. J. Agr. Food Chem. 36, 1202-1206.

Ulbricht, T.L.V. \& Southgate, D.A.T., 1991. Coronary heart disease: seven dietary factors. Lancet 338, 985-992.

Vlaeminck, B., Fiavez, V., Cabrita, A.R.J., Fonseca, A.J.M. \& Dewhurst, D., 2006. Factors affecting odd- and branched-chain fatty acid in milk: A review. Anim. Feed Sci. Technol. 131, 389-417.

Webb, E.C. \& Erasmus, L.J., 2013. The effect of production system and management practices on the quality of meat products from ruminant livestock. S. Afr. J. Anim. Sci. 43, 413-423. 